\title{
EDITORIAL
}

\section{Human-mediated introductions of Australian acacias- a global experiment in biogeography}

Running header Wattles: a model group for invasion science

David M. Richardson ${ }^{1}$, Jane Carruthers ${ }^{2}$, Cang Hui1 ${ }^{1}$, Fiona A.C. Impson ${ }^{3,4}$, Joseph T. Miller ${ }^{5}$, Mark P. Robertson ${ }^{6,1}$, Mathieu Rouget ${ }^{7}$, Johannes J. Le Roux ${ }^{1}$ \& John R.U. Wilson 8,1

1 Centre for Invasion Biology, Department of Botany \& Zoology, Stellenbosch University, Matieland 7602, South Africa

2 Department of History, University of South Africa, P.O. Box 392, Unisa, 0003, South Africa

3 Zoology Department, University of Cape Town, Rondebosch 7701, South Africa

4 Plant Protection Research Institute, Private Bag X5017, Stellenbosch 7599, South Africa

5 Centre for Australian National Biodiversity Research, CSIRO Plant Industry, GPO Box 1600, Canberra, Australia

6 Department of Zoology and Entomology, University of Pretoria, Pretoria 0002, South Africa

7 Department of Plant Science, University of Pretoria, Pretoria 0002, South Africa

8 South African National Biodiversity Institute, Private Bag X7, Claremont 7735, Cape Town, South Africa.

Correspondence: David M. Richardson, Centre for Invasion Biology, Department of Botany \& Zoology, Stellenbosch University, Matieland 7602, South Africa. E-mail: rich@sun.ac.za 


\section{ABSTRACT}

Aim Australian acacias (1012 recognised species, previously grouped in Acacia subgenus Phyllodineae, which are native to Australia) have been moved extensively around the world by humans over the past 250 years. This has created the opportunity to explore how evolutionary, ecological, historical, and sociological factors interact to affect the distribution, usage, invasiveness, and perceptions of a globally important group of alien plants. This editorial provides the background for the 20 papers in this special issue of Diversity and Distributions that focuses on the global cross-disciplinary experiment of introduced Australian acacias.

Location Australia and global

Methods The papers of the special issue are discussed in the context of a unified framework for biological invasions. Distributions of species were mapped across Australia, their representation in bioclimatic zones examined, and the potential global distribution of the group modelled. By collating a variety of different lists we determined which Australian acacias have reached different stages in the introduction-naturalization-invasion continuum in different parts of the world. Paradigms and key research questions that underpin the current understanding of issues relating to salient barriers, stages, and management perceptions are sketched.

Results According to our global database of Australian acacia records, 386 species have been moved outside Australia by human agency, 71 species have been described as naturalized or weedy, and 23 can be unequivocally categorised as invasive. Climatic models suggest that about a third of the world's land-surface is climatically suitable for Australian acacias. Many species are commercially important crops or are useful for other purposes and have been extensively planted, and many different human perceptions of Australian acacias exist in different parts of the world. The papers in the special issue cover all of the barriers, stages, and processes that define biological invasions and touch on many aspects: history and the human dimension; aspects of the species pool; species traits; biotic interactions; climate and niche; and management.

Main conclusions Australian acacias are an excellent model group for examining interactions between evolutionary, ecological and socio-economic drivers of species introductions. New insights have emerged on the biological, ecological and evolutionary correlates of naturalization and invasion, but human usage factors permeate all explanatory models. 
Keywords Biological invasions, Acacia, Fabaceae, natural experiments, Racosperma, translocations, tree invasions

\section{(A) INTRODUCTION}

Humans have moved species around the world for thousands of years, but the number of species involved, the rate and magnitude of movement, and the number of pathways involved have increased massively over the past three centuries (Ricciardi, 2007; Wilson et al., 2009). Non-native species are now dominant components of many ecosystems. They provide goods and services that sustain burgeoning human populations, but are also important drivers of global change and, in many cases, of ecosystem alteration (Pyšek \& Richardson, 2010). The human-mediated re-shuffling of the world's biota also provides opportunities for testing ecological and evolutionary theories. The scientific study of the movement of species to areas outside their natural ranges and the fate of these species in their new ecosystems has become an important sub-discipline of biogeography and ecology (Richardson, 2011a,b).

The ways in which different sectors of human societies perceive non-native species are becoming increasingly complex and change over time (e.g. Warren, 2007; Richardson et al., 2008; Warren, 2008). In particular, species which are commercially important or that are valued by different sectors of society, but which are also problematic invaders in parts of their range, pose special challenges for those tasked with managing natural resources. The human dimensions of invasions are receiving increased attention, drawing interest from researchers in the humanities (ethicists, historians, philosophers, sociologists, etc) and those studying human behaviour (e.g., movement patterns; Brockman et al., 2006; González et al., 2008). The rich literature on biological invasions is however compartmentalized, with too little infusion of insights across disciplines (Kueffer \& Hirsch Hadorn, 2008). The set of papers in this special issue of Diversity and Distributions aims to bring together the work of scholars in a variety of disciplines to initiate a truly comparative, multi-disciplinary conversation, and to encourage genuinely trans-disciplinary work. Australian acacias provide a good study system for this purpose.

Among tree genera of the world, three taxa make up a very large part of plantings of species outside their native ranges (where they may be termed alien, exotic, or non-native): Acacia Mill. (sensu lato), Eucalyptus L'Hér. and Pinus L. Of these, Acacia and Pinus are particularly well represented in global lists of invasive alien species (those that have spread from introduction 
sites in novel environments) (Richardson \& Rejmánek, 2011). Pinus has been well studied, both within its natural range and in the many parts of the world where they are grown as exotics (Richardson, 1998; Richardson et al., 2007). The invasion ecology and underlying mechanisms associated with range changes of pines have also been well studied (Richardson, 2006; Richardson et al., 2008; Simberloff et al., 2010; Carrillo-Gavilan \& Vila, 2010; Essl et al., 2010; Nunez \& Medley, 2011; Procheş et al., 2011). Eucalypts, on the other hand, although planted at a similar grand scale worldwide, have been much less successful as invasive species, with only a handful of major invaders (Richardson \& Rejmánek, 2011). Not surprisingly, the invasion ecology of eucalypts is less well known than that of pines (Rejmánek \& Richardson, 2011).

Like pines and eucalypts, many acacias (a polyphyletic group comprising c. 1300 species; see Appendix 1 for details on taxonomy) and especially Australian acacias have been widely planted outside their natural ranges for centuries. Different species have fared differently as nonnatives, even under similar environments and with similar introduction histories. Nevertheless, landscapes in many parts of the world are now dominated by planted or self-sown stands of Australian acacias. Some species are crops of major commercial importance and many others have considerable value for a wide range of purposes (Griffin et al., 2011; Kull et al., 2011; van Wilgen et al., 2011). Some Australian acacias are among the most widespread and damaging of all invasive plants (Lowe et al., 2000; Gaertner et al., 2009; Richardson \& Rejmánek, 2011), others are only moderately weedy, and yet others are not known to invade, although some of the last-mentioned are recent introductions (Wilson et al., 2011) and likely represent a substantial invasion debt. The human perception of Australian acacias differs markedly in different parts of the world where they are grown as exotics. Even within regions, different sectors of human society view different species very differently and within distinct cultural and historical contexts (Carruthers et al., 2011; Kull et al., 2011). Attempts to manage Australian acacias have taken many forms in different parts of the world (Wilson et al., 2011). Management policies, legislation, and best-practice guidelines in different regions are the result of the complex interplay between cultural and socio-political factors, shaped by environmental drivers and disturbance regimes (e.g., Roura-Pascual et al., 2010).

The long history of widespread transfers and planting of Australian acacias in many parts of the world has created an outstanding natural experiment with considerable opportunities for gaining insights on factors that influence, for example: 1) the ways that different introduced species have been assimilated into ecosystems, local human cultures and value systems and how this has changed over time and under different circumstances; 2) why species have shown different degrees of invasiveness in new environments; 3 ) why certain ecosystems are more 
susceptible to acacia invasions than others; 4) the function of acacias in recipient environments and their capacity to alter ecosystem functioning and services; and 5) the factors that influence the evolution of management responses in different regions. The multiple dimensions of the natural experiment may suggest new approaches and priorities for the emerging field of invasion science (Richardson, 2011b). It also has much potential for helping to shape the dimensions of and priorities for the young field of conservation biogeography which applies biogeographical principles, theories, and analyses to problems regarding biodiversity conservation (Richardson \& Whittaker, 2010). Alien species pose a bewildering array of challenges (and some opportunities) for conservationists, and new frameworks and tools are needed to assimilate the multitude of perspectives for devising appropriate and sustainable management strategies.

\section{(A) AUSTRALIAN ACACIAS AS A MODEL SYSTEM FOR INVASION SCIENCE}

Australian acacias provide a good opportunity for a multi-disciplinary cross examination of the many dimensions involved in the global expansion of an important group of plants for at least the following reasons:

- The group contains a very large number of taxa (1012 species were recognised as of October 2010), at least a third of which have been moved by humans to areas outside their natural ranges (Griffin et al., 2011; Tables 1 and 2; Appendix S1) of which 23 are confirmed as invasive (sensu Pyšek et al., 2004)(Richardson \& Rejmánek, 2011) and many more are naturalized (Table 1).

- The group has a well-resolved taxonomy and phylogeny (Miller et al., 2011). This provides the opportunity to explore whether invasiveness has a phylogenetic signature; indeed invasive and naturalized species come from several, but not all, major clades within the genus (Miller et al., 2011).

- Australian acacias are present in most major biogeographical regions in Australia (Fig. 1). Adaptations necessary to persist across such a wide range of environmental conditions mean that different taxa are differentially pre-adapted to survive and flourish in many different parts of the world (analogous conditions to those that exist in different parts of the Australian range of Acacia exist in many parts of the world; Fig. 2).

- The native-range distribution of all taxa is well known and point-locality data are available from the Australia's Virtual Herbarium, facilitating detailed biogeographical and macroecological analyses (Hui et al., 2011) and species distribution modelling (Thompson et al., 2011; Webber et al., 2011). 
- Many Australian acacias show exceptionally high levels of intra-specific divergence and variation (Le Roux et al., 2011). As introductions of taxa to new regions have sampled different proportions of the genetic diversity of native populations, contemporary and micro-evolutionary processes and mechanisms associated with persistence and invasiveness across multiple species can be assessed both at inter and intra-specific levels (Le Roux et al., 2011; Thompson et al., 2011).

- The extensive and various human usages have involved artificial selection for various traits, many of which — such as growth rate, robustness, and environmental tolerancecould potentially influence invasion success (Griffin et al., 2011).

- Australian acacias have been widely utilised for many purposes in many parts of the extra-Australian range. Receiving environments have rich and diverse socio-cultural histories that have influenced the need for introductions of Australian acacias and influence how they are assimilated into changing cultures and value systems (Carruthers et al., 2011). These pave the way for a new synthesis of the full suite of human connections with Australian acacias outside their natural ranges (Kull et al., 2011).

- Introductions and the fate of plantings of Australian acacias as exotics are generally well documented (in some cases exceptionally well; e.g. Poynton, 2009), making it feasible to explore factors associated with successes and failures and testing the validity of particular paradigms associated with different introduction histories, e.g. multiple vs. single introduction events (Le Roux et al., 2011), the role of different ecophysiological and life-history traits (Castro-Díez et al., 2011; Gallagher et al., 2011; Gibson et al., 2011; Morris et al., 2011), and features of natural ranges (Hui et al., 2011) in determining invasiveness; and how metrics of human usage interact with these factors (Castro-Díez et al., 2011).

- A few species have been very widely planted in massive numbers in commercial plantations (Griffin et al., 2011). Introduced Australian acacias are now dominant components of ecosystems in many parts of the world (Fig. 3), where contrasting conditions have exposed them to a wide range of potential habitats and novel biotas.

- A large literature exists on many aspects of Australian acacias as non-native species, facilitating intra-specific comparisons on many fronts.

- Introductions of Australian acacias to a wide range of ecosystems provides many opportunities to explore interactions between trophic levels that contribute to invasive success (notably in the case of mutualisms involving soil microbiota; RodríguezEcheverría et al., 2011), mediate their influence on native biota (Le Maitre et al., 2011; 
Veldtman et al., 2011), and affect the health of species of commercial importance (Wingfield et al., 2011).

- Similarly, the long history of management in some countries, but relatively recent initiation of interventions in others, creates an ideal situation for exchanging lessons and building generalisations for best practice (Le Maitre et al., 2011; Moore et al., 2001; van Wilgen et al., 2011; Wilson et al., 2011).

This paper provides background and context for the wide range of issues covered in the special issue within a proposed unified framework for biological invasions (Blackburn et al., 2011) (Fig 4). The following sections elucidate some of the key factors that have shaped (and continue to shape) the global expansion of Australian acacias. Particular attention is given to themes touched upon in the special issue papers.

\section{(A) THE SPECIES POOL: AUSTRALIAN ACACIAS AT HOME}

Acacia subgenus Phyllodineae has undergone spectacular radiations in Australia. Of the 1022 species in subgenus Phyllodineae, only 17-20 species have native ranges that extend outside Australia, and only 10 are exclusively extra-Australian (Table 1), confined to the Indo-Pacific region. Within Australia the east-west divide acted as an important evolutionary force because similar climatic and edaphic conditions occur on both sides of the Nullabor Plain. For example, Mediterranean-type climates occur in both south-western Western Australia and in South Australia, but only about 50 Acacia species have natural ranges that include both regions. Acacias are found in almost all habitat types across the continent, and, together with eucalypts, epitomise the Australian landscape. The onset of aridity (c. 15 mya), together with old and nutrient-poor soils and complex interactions with climatic fluctuations and fire across much of the continent have stimulated a rapid radiation of unique adaptations in both acacias and eucalypts. For acacias, centres of high species richness, such as the Mediterranean-type climate zone of the south-western corner of Western Australia (Fig. 1), have been foci of recent evolutionary divergence and also act as refugia favouring the persistence of some relict forms (Hopper \& Maslin, 1978).

Possibly the most characteristic trait of many members of the group is the presence of persistent evergreen phyllodes (modified petioles)—scleromorphic features with various xeromorphic mechanisms. Sister lineages of Acacia subgenus Phyllodineae have bipinnate leaves and the modified phyllodes appear to be a basal trait that was subsequently lost on at least three independent occasions (Murphy et al., 2003). Phyllodes are highly variable in the 
group, differing in size, shape and nervature. These evolutionary changes are complex, and homology among phyllode variants is not well understood. However, it is hypothesized that phyllode architecture has been selected through changing environmental conditions, specifically the change from mesic to arid landscapes. Like many leguminous species, all Australian acacias are thought to have a symbiotic association with rhizobia which allows them to fix atmospheric nitrogen. The vegetation of Australia is unusual in that nitrogen-fixing plants, particularly acacias, are major components of most vegetation types. Some acacias combine fungal ectomycorrhizae and bacterial symbionts to assimilate nitrogen. Acacia species have particular pollination syndromes with low energy allocation to floral nectar but with high pollen rewards. Acacias have polyad pollen grains to maximize seed set after pollination. Other adaptations that have arisen as a consequence of this adaptive radiation are a suite of mechanisms to survive and persist fire (e.g., fire-stimulated germination of soil-stored seeds, and resprouting) and, in some species, the utilization of animals for seed dispersal (elaiosomes to attract ants and arils to attract birds) (O’Dowd \& Gill, 1986; Orians \& Milewski, 2007). These features might explain the diversity and dominance of Acacia species across such a range of environments in Australia (Fig. 1).

Human-mediated transport of species beyond their historical ranges, especially in the last century, has breached biogeographical barriers within Australia, allowing many acacias to occupy novel habitats where some species have become naturalized or invasive (sensu Pyšek et al., 2004), changing the continental-scale distribution pattern of the genus. At least 11 species are classified as invasive within Australia (Richardson \& Rejmanek, 2011) and many more are established/naturalized outside their natural ranges. Within Australia, the ranges of some acacias have altered with human activities. Land transformation through agriculture and urbanization have led to range reductions but also to expansions, thus altering the dynamics of Australian acacias even within Australia.

\section{(A) THE JOURNEY: AUSTRALIAN ACACIAS ON THE MOVE [THE GEOGRAPHIC BARRIER]}

Whereas most inter-continental movements of plants in the colonial era was from the "Old World" to the "New World", Australian acacias and eucalypts represent a special case in "ecological imperialism" (Crosby, 1986). Species from both groups became conspicuous, even dominant components in many regions of the world soon after they were introduced and widely planted. The export of Australian acacias to other parts of the world began soon after the arrival of Europeans in Australia in 1788. Many Australian acacias were growing in Europe by the end of the first quarter of the $19^{\text {th }}$ century (Cavanagh, 2006). Kull \& Rangan (2008) provide a 
succinct summary of the main phases of the dissemination of Australian acacias around the world. They separate four groups of Australian acacias in the "Outbound from Australia" component of worldwide "acacia exchanges": cool-climate wattles; Acacia melanoxylon; tropical acacias; and arid-zone acacias. Besides the different species involved in these exchanges, the four groups differ importantly in terms of the agencies responsible for inter-continental, regional, and local movements. South Africa received a greater diversity and magnitude (in terms of numbers of introduction events and total propagule pressure) of Australian acacia introductions than any other region in the $19^{\text {th }}$ century. About 70 species were introduced, most of them in the mid 19th century (Poynton, 2009; Table 1). Another major boom in introductions and plantings to additional countries outside Australia occurred in around 1980 (Griffin et al., 2011).

Details of introduction histories of alien species are important for understanding many aspects of their performance in new environments. Although (putative) dates of introduction and other aspects, such as approximate number of seeds and likely provenance, are available for some species (e.g., Poynton, 2009), data are sparse for most species and the reliability of available data is questionable in some cases. Molecular techniques provide exciting opportunities for enhancing our understanding of mechanisms underlying successful invasions by shedding light on key facets of introduction histories such as; the number of introductions (single vs. multiple - shown to have profound implications for performance), the relationship between genetic diversity of introduced species and their performance, the occurrence and extent of hybridization within or between species, and the identification of native provenances (Le Roux \& Wieczorek, 2009). Elucidation of subsequent processes and the fate of introduced species rely on the availability of accurate data on the extent to which species in a given group have been introduced to new regions and have had sufficient time to "sample" new habitats. Table 1 shows the rich data available for exploring the reasons for the number of Australian Acacia species at different stages of the introduction-naturalization-invasion continuum in different parts of the world.

\section{(A) ARRIVING: HOMES AWAY FROM HOME}

Most Australian acacias were transported to foreign environments as seeds and in some cases, (e.g. in South Africa), in very large numbers that were immediately sown into natural ecosystems for specific purposes. Considerable care was sometimes taken to nurture young plants to protect them from competition from native plants and various other factors such as herbivory. In the case of commercially important agroforestry species, natural vegetation was 
cleared to remove competing native species. Many species were intentionally very widely disseminated by humans in new regions, rapidly creating large seed pools at multiple foci. The many ways in which Australian acacias were welcomed and nurtured in their new homes and the needs that they satisfied were crucial for determing subsequent trajectories of performance, abundance, and distribution, as well as their impacts on ecosystems and the extent to which they were welcomed or detested by human societies.

Australia has a wide range of environments and bioclimatic zones. Fig. 2 shows that roughly a third of the earth's land area has bioclimatic conditions similar to those that exist within the native ranges of Australian acacias. This is the template upon which most introductions have taken place. Among regions that have received imports of Australian acacias, perhaps none is potentially more suitable in terms of broad-scale bioclimatic conditions than South Africa. All of South Africa's seven biomes have equivalent bioclimatic zones in Australia, and Australia has more than four times the land area with South Africa-like climate than exists in South Africa (Richardson \& Thuiller, 2007). Broad-scale climatic matching is widely recognized as a fundamental requirement for the success of introduced plants. It is thus not surprising that all regions where Australian acacias are listed as invasive (Richardson \& Rejmanek, 2011) were identified as being bioclimatically equivalent to areas within the range of a large number of Australia acacias (Fig. 2). No other region has more invasive Australian acacias than South Africa (Richardson \& Rejmanek, 2011).

How invasive species interact with native biota is an important focus area in invasion biology. Among the key questions are: how does competition with native species influence community structure; and how do introduced species infiltrate seed dispersal and pollination networks and food webs? For legumes that form associations with nitrogen-fixing bacteria, a crucial issue is whether introduced species can form novel associations with native bacteria or whether they rely on compatible symbionts from the native range (Richardson et al., 2000a). Despite the wealth of literature available on native-invasive interactions, surprisingly little is known about these aboveground-belowground interactions that are clearly vital mediators of the fate of introduced species (Bardgett \& Wardle, 2010). Only very recently have researchers started to explore whether successful establishment depends on the degree of promiscuity; in other words, whether the ability to form associations with a wide range of bacteria is associated with wider environmental tolerance. Even a decade ago, almost nothing was known about these issues for introduced acacias (Richardson et al., 2000a). Much work has been done in recent years (Rodríguez-Echeverría, 2010), but many questions remain to be answered before a predictive understanding of this aspect of the biology of Australian acacias, and legumes in 
general, can be incorporated into models for predicting how different species will fare in different foreign environments (Rodríguez-Echeverría et al., 2011).

\section{THE CYCLE OF LIFE: REPRODUCTION AND DISPERSAL}

Traits related to reproduction and dispersal are crucial for naturalization and invasion of species in new environments. Substantial advances have been made recently in understanding the links between particular traits and invasiveness of plants. Three main approaches have been followed in examining this issue: alien-alien congeneric comparisons, alien-native congeneric comparisons, and multispecies studies. Each approach has its advantages (Pyšek \& Richardson, 2007), but detailed studies of congeners are probably the most powerful approach (Richardson, 2006). Although the large number of taxa of Australian acacias is attractive for such studies, a major hurdle in this group is the shortage of data on many species, especially those that have not been widely introduced around the world and/or that are not of special importance to humans. Despite this problem, important opportunities exist to contrast levels of success as introduced species with different traits. This is important, since information on traits is widely used in screening protocols to identify species with a high risk of becoming invasive (e.g. Tucker \& Richardson, 1995).

\section{HERE TO STAY? THE HUMAN DIMENSION OF INTRODUCED ACACIAS}

Several features of Australian acacias make them important to humans. The foliage, seeds, wood and bark of many species have been used by humans for centuries as fodder for livestock, sources of famine food, medicines and fuel. The desire for these products has lead to extensive human-assisted movement of some species to areas far removed from their native ranges. In particular, about a third of Australian acacias are trees and several species are key components of agroforestry in the tropics (Richardson et al., 2004). Their rapid growth rates, ability to survive and flourish in nutrient-poor, arid or degraded sites and their dense wood makes them sought after for different types of forestry in many parts of the world. Many species also have attractive forms, floral displays, or foliage, making them increasingly popular for ornamentation (Ratnayake \& Joyce, 2010).

Together with the scientific importance of introduced acacias and what they illuminate in terms of dispersal, human-mediated introductions of Australian acacias also contain the history and expectations of both exporters and importers of the species. The exchanges and their effects 
thus raise fresh questions for historians, philosophers and social scientists. Their very introduction has polarised scientific politics around the human values of acacias in their home ranges in Australia (where they are of symbolic value) and the places to which they have been introduced where, in some cases, having first been celebrated they later became demonised. Questions around the fundamental principles and philosophy of invasion biology are also germane to this global experiment. Historians have had to come to grips with the motivations (which have not always been strictly utilitarian) of introducing Australian acacias and with the economic benefits that have accrued from a variety of acacia products such as timber, fuelwood, perfume, food and animal fodder. Philosophers have also been encouraged by invasion biology and the acacia experiment to give close consideration to environmental aesthetics and a system of 'values'. Social scientists have examined how these introductions have impacted on the culture and daily life of the people who use acacias in these different ways and how these relationships have changed over time. A range of ideas and perceptions relating to ecological restoration and the nature of science have also been uncovered by this global experiment.

\section{CONCLUSIONS}

The Australian environment and its evolutionary history have served as a factory for a highly diverse flora that is extremely well adapted for survival, growth, and proliferation in many parts of the world that have, until recently, been isolated from Australia. The evolutionary milieu, fortuitously, has also manufactured a bewildering number of plants that are, for diverse reasons, highly sought after by humans across the globe. These two factors, in intricate combination with complex socio-political and cultural histories, have designed the natural experiment that is the subject of this special issue of Diversity and Distributions. As with all natural experiments in biogeography and ecology, the design is imperfect. Among the imperfections are the following:

- Species have not been moved out their native ranges to the same extent (in similar numbers and over equivalent periods) and many have not been moved at all, creating a biased set of species (Fig. 5) and creating challenges for teasing apart human factors from biological mechanisms as mediators of invasion success.

- Traits associated with ecological performance and thus potential invasiveness in new environments are intricately linked with traits associated with usefulness of species to humans (neither set of traits maps evenly across the phylogeny or functional groups in the group). This complicates attempts to separate proximate and ultimate explanations 
for different degrees of naturalization/invasion of introduced species, since propagule pressure may override and mask other contributing factors.

- Accurate data on most traits is available for only a small sample of species in the group for the most part only for those species that are most useful to humans (and a few taxa of special interest in their native range). This complicates attempts to correlate performance as introduced species with traits across the full spectrum of species.

Despite these challenges, the studies collected in this special issue demonstrate many innovative approaches for gaining important new insights on the many factors that influence: how and why Australian acacias have succeeded in expanding their range so dramatically in recent centuries; how their presence, distribution, abundance and interactions with resident biota and ecosystems are perceived by humans in a broad spectrum of social settings; and the options open for different forms of management in the face of complex human value systems and a rapidly changing environment (Low, 2011).

Although Australian acacias are already dominant components of many ecosystems outside Australia, scholarly reflection and scientific investigation of the natural experiment have only just begun. Pathways of transfer and dissemination are changing continuously, as are the habitats and socio-political environments into which the species are being introduced. So too are the societies in which these species grow. Are some Australian acacias "super species" (sensu Hamilton, 2010) that will increasingly dominate large parts of the planet? If so, how can we manage these species to maximize their potential usefulness while mitigating the damage that they cause to ecosystems in some regions and under certain situations? It is hoped that this special issue will serve as a catalyst for further studies that will provide the foundation needed to guide the objective management of Australian acacias in all the many environments where they now occur.

\section{ACKNOWLEDGEMENTS}

The Oppenheimer Memorial Trust and Stellenbosch University funded the workshop hosted by the DST-NRF Centre of Excellence for Invasion Biology in Stellenbosch in October 2010 at which early versions of all contributions to this special issue of Diversity and Distributions were presented. We also acknowledge funding from the Working for Water Programme and the DSTNRF Centre of Excellence for Invasion Biology through their collaborative project on "Research for Integrated Management of Invasive Alien Species" which paved the way for the 
transdisciplinary work on Australian acacias. All the delegates at the workshop are thanked for contributing to discussions and subsequent correspondence. For several months the 104 authors from 18 countries (based on primary institutional addresses) who contributed to this special issue formed a virtual "global acacia college"; we thank all authors for their willingness to respond to a myriad of queries. All manuscripts were reviewed following the normal editorial process for Diversity and Distributions (DDI). Each manuscript was handled by an Associate Editor (AE) of DDI; besides the AEs represented among the editors of the special issue, Mark Burgman, Janet Franklin, Andrew Knight, Andrew Lowe, Petr Pyšek, Marcel Rejmánek, and Mathieu Rouget kindly devoted time to the project. We thank them, and the many anonymous referees, for their attention to detail in the face of tight deadlines and other challenges associated with the production of a large special issue of inter-linking contributions. Christy Momberg handled the logistics of the workshop with great efficiency. DMR acknowledges support from the Hans Sigrist Foundation that funded several trips associated with research relating to Australian acacias.

Data from the Australia's Virtual Herbarium were used with permission of the Council of Heads of Australasian Herbaria Inc. 


\section{REFERENCES}

Australia's Virtual Herbarium (2010) http://www.ersa.edu.au/avh. Council of Heads of Australasian Herbaria Inc. (accessed July 2010)

Bardgett, R.D. \& Wardle, D.A. (2010) Aboveground-belowground linkages. Biotic interactions, ecosystem processes, and global change. Oxford University Press, Oxford.

Bentham, G. (1875) Revision of the Suborder Mimoseae. Transactions of the Linnaean Society of London, 30, 335-664.

Blackburn, T.M., Pyšek, P., Bacher, S., Carlton, J.T., Duncan, R.P., Jarošík, V., Wilson, J.R.U. \& Richardson, D.M. (2011). A proposed unified framework for biological invasions. Trends in Ecology \& Evolution, 26, 333-339.

Brockmann, D., Hufnagel, L. \& Geisel, T. (2006) The scaling laws of human travel. Nature, 439, 462-465.

Brown, G.K. Murphy, D.J., Miller, J.T. \& Ladiges, P.Y. (2008) Acacia s.s. and its relationship among tropical legumes, Tribe Ingeae (Leguminosae: Mimosoideae). Systematic Botany, 33, 739-751. Candolle, A.P. de (1825) Prodromus systematis naturalis regni vegetabilis. Vol.2. Sumptibus Sociorum Treuttel et Würtz, Paris.

Carrillo-Gavila, M. \& Vila, M. (2010) Little evidence of invasion by alien conifers in Europe. Diversity and Distributions, 16, 203-213.

Carruthers, J., Robin, L., Hattingh, J., Kull, C., Rangan, H. \& van Wilgen, B.W. (2011) A native at home and abroad: the history, politics, ethics and aesthetics of acacias. Diversity and Distributions, 17 (in press) DOI: 10.1111/j.1472-4642.2011.00779.x Castro-Díez, P., Godoy, O., Saldaña, A. \& Richardson, D. M. (2011) Predicting invasiveness of Australian acacias on the basis of their native climatic affinities, life-history traits and human use. Diversity and Distributions, 17 (in press) DOI: 10.1111/j.1472-4642.2011.00778.x. Cavanagh, T. (2006) Historical aspects of wattles: The cultivation of Australian acacias in Great Britain and Europe during the 18th and 19th centuries. Acacia 2006: Knowing and growing Australian wattles, National Herbarium of Victoria and Australian Plants Society (SGAP Victoria) Inc., Melbourne.

Clarke, H.D., Downie, S.R. \& Seigler, D.S. (2000) Implications of chloroplast DNA restriction site variation for systematics of Acacia (Fabaceae: Mimosoideae). Systematic Botany, 25, 618-632. Crosby, A.W. (1986) Ecological imperialism: the biological expansion of Europe, 900-1900. Cambridge University Press, Cambridge.

Essl, F., Moser, D., Dullinger, S., Mang, T. \& Hulme, P.E. (2010) Selection for commercial forestry determines global patterns of alien conifer invasions, Diversity and Distributions, 16, 911-921. 
Gallagher, R. V., Leishman, M. R., Miller, J. T., Hui, C., Richardson, D. M., Suda, J. \& Trávníček, P. (2011) Invasion success of introduced Australian acacias: the role of species' traits and genome size. Diversity and Distributions, 17 (in press). DOI: 10.1111/j.1472-4642.2011.00805.x

Gaertner, M., den Breeÿen, A., Hui, C. \& Richardson, D.M. (2009) Impacts of alien plant invasions on species richness in Mediterranean-type ecosystems: a meta-analysis. Progress in Physical Geography, 33, 319-338.

Gibson, M., Richardson, D.M. Marchante, E., Marchante, H., Rodger, J.G., Stone, G.N., Byrne, M., Fuentes-Ramírez, A., George, N., Harris, C., Johnson, S.D., Le Roux, J.J., Miller, J.T., Murphy, D.J. Pauw, A., Prescott, M.N., Wandrag, E.M., Wilson, J.R.U. (2011) Reproductive ecology of Australian acacias: important mediator of invasive success? Diversity and Distributions, 17 (in press). González, M.C., Hidalgo, C.A. \& Barabási, A.-L. (2008) Understanding individual human mobility patterns. Nature, 453, 779-782.

Griffin, A.R., Midgley, S.J., Bush, D., Cunningham, P.J. \& Rinaudo, A.T. (2011) Global uses of Australian acacias: recent trends and future prospects. Diversity and Distributions, 17 (in press). DOI: 10.1111/j.1472-4642.2011.00814.x.

Hamilton, G. (2010) Super species. The creatures that will dominate the planet. Firefly books, Buffalo, N.Y.

Hijmans, R.J., Cameron, S.E., Parra, J.L., Jones, P.G. \& Jarvis, A. (2005) Very high resolution interpolated climate surfaces for global land areas. International Journal of Climatology, 25, 1965-1978.

Hopper, S.D. \& Maslin, B.R. (1978) Phytogeography of Acacia in Western Australia. Australian Journal of Botany, 26, 63-78.

Hui, C., Richardson, D.M., Robertson, M.P., Wilson, J.R.U. \& Yates, C.J. (2011) Macroecology meets invasion ecology: linking the native distributions of Australian acacias to invasiveness. Diversity and Distributions, 17 (in press). DOI: 10.1111/j.1472-4642.2011.00804.x

Hutchinson, M.F., McIntyre, S., Hobbs, R.J., Stein, J.L., Garnett, S. \& Kinloch, J. (2005) Integrating a global agro-climatic classification with bioregional boundaries in Australia. Global Ecology and Biogeography, 14, 197-212.

Kueffer, C. \& Hirsch Hadorn, G. (2008) How to achieve effectiveness in problem-oriented landscape research: the example of research on biotic invasions. Living Review of Landscape Research, 2, http://www.livingreviews.org/lrlr-2008-2.

Kull, C.A. \& Rangan, H. (2008) Acacia exchanges: Wattles, thorn trees, and the study of plant movements. Geoforum, 39, 1258-1272.

Kull, C.A., Shackleton, C.M., Cunningham, P.S., Ducatillon, C., Dufour-Dror, J.-M., Esler, K.J., Friday, J.B., Gouveia, A.C., Griffin, A.R., Marchante, E.M., Midgley, S.J., Pauchard, A., Rangan, H., Richardson, D.M., Rinaudo, T., Tassin, J., Urgenson, L.S., von Maltitz, G.P., Zenni, R.D. \& Zylstra, 
M.J. (2011) Adoption, use, and perception of Australian acacias around the world. Diversity and Distributions, 17 (in press). DOI: 10.1111/j.1472-4642.2011.00783.x.

Le Maitre, D.C., Gaertner, M., Marchante, E., Ens, E.-J., Holmes, P.M., Pauchard, A., O’Farrell, P.J., Rogers, A.M., Blanchard, R., Blignaut, J. \& Richardson, D.M. (2011) Impacts of invasive Australian acacias: implications for management and restoration. Diversity and Distributions, 17 (in press) DOI: $10.1111 / \mathrm{j} .1472-4642.2011 .00816 . \mathrm{x}$

Le Roux, J.J., Brown, G., Byrne, M., Ndlovu, J., Richardson, D.M., Thompson, G.D. \& Wilson, J.R.U. (2011) Phylogeographic consequences of different introduction histories of invasive Australian Acacia species and Paraserianthes lophantha (Fabaceae) in South Africa. Diversity and Distributions, 17 (in press). DOI: 10.1111/j.1472-4642.2011.00784.x

Le Roux, J. \& Wieczorek, A.M. (2009) Molecular systematics and population genetics of biological invasions: towards a better understanding of invasive species management. Annals of Applied Biology, 154, 1-17.

Low, T. (2011) Invasive aid: Weedy Australian acacias. Biological Invasions (in press).

Lowe, S., Browne, M., Boudjelas, S. \& De Poorter, M. (2000) 100 of the world's worst invasive alien species. A selection from the Global Invasive Species Database. IUCN, Auckland, New Zealand. http://www.issg.org/database Available online.

Luckow, M., Miller, J.T., Murphy, D.J. \& Livshultz, T. (2003) A phylogenetic analysis of the Mimosoideae (Leguminosae) based on chloroplast DNA sequence data. Advances in legume systematics, part 10, (ed. by B.B. Klitgaard and A. Bruneau), pp. 197-220. Royal Botanic Gardens, London.

Maslin, B.R., Miller, J.T. \& Seigler, D.S. (2003) Overview of the generic status of Acacia (Leguminosae : Mimosoideae). Australian Systematic Botany, 16, 1-18.

McNeill, J. \& Turland, N.J. (2010) The conservation of Acacia with A. penninervis as conserved type. Taxon, 59, 613-616.

Miller, J. T., Murphy, D. J., Brown, G. K., Richardson, D. M. \& González-Orozco, C. E. (2011) The evolution and phylogenetic placement of invasive Australian Acacia species. Diversity and Distributions, 17 (in press) DOI: 10.1111/j.1472-4642.2011.00780.x.

Miller, J.T., Bayer, R.J. (2000) Molecular phylogenetics of Acacia (Fabaceae: Mimosoideae) based on chloroplast TRNK/MATK and nuclear histone H3-D sequences. Advances in legume systematics 9. (ed. by P.S. Herendeen and A. Bruneau), pp. 181-200. Royal Botanic Gardens, Kew, London. 
Miller, J.T. \& Bayer, R.J. (2001) Molecular phylogenetics of Acacia (Fabaceae: Mimosoideae) based on the chloroplast matK coding sequence and flanking trnK intron spacer regions.

American Journal of Botany, 88, 697-705.

Miller, P. (1754). The gardeners' dictionary. Abr. 4th ed. Self published, London.

Moore, G., Smith, G.F., Figueiredo, E., Demissew, S., Lewsi, G., Lewis, G., Schire, B., Rico, L. \& van Wyk, A.E. (2010) Acacia, the 2011 Nomenclature Section in Melbourne, and beyond. Taxon, 59, 1188-1195.

Moore, J.L., Runge, M.C., Webber, B.L. \& Wilson, J.R.U. (2011) Contain or eradicate? Optimising the management goal for Australian acacia invasions in the face of uncertainty. Diversity and Distributions, 17 (in press). DOI: 10.1111/j.1472-4642.2011.00809.x.

Morris, T.L., Esler, K.J., Barger, N.N., Jacobs, S.M. \& Cramer, M.D. (2011) Ecophysiological traits associated with the competitive ability of invasive Australian acacias. Diversity and Distributions, 17 (in press). DOI: 10.1111/j.1472-4642.2011.00802.x

McNeill, J. \& Turland, N.J. (2010) The conservation of Acacia with A. penninervis as conserved type. Taxon, 59, 613-616.

Murphy, D.J., Brown, G.K., Miller, J.T. \& Ladiges, P.Y. (2010) Molecular phylogeny of Acacia s.s. (Mimosoideae: Leguminosae) - evidence for major clades and informal classification. Taxon, 59, 7-19.

Murphy, D.J., Miller, J.T., Bayer, R.J. \& Ladiges P.Y. (2003) Molecular phylogeny of Acacia subgenus Phyllodineae (Mimosoideae: Leguminosae) based on DNA sequences of the internal transcribed spacer region. Australian Systematic Botany, 16, 19-26.

Nuñez, M.A. \& Medley, K.A. (2011) Pine invasions: climate predicts invasion success; something else predicts failure. Diversity and Distributions, 17, 703-713.

O'Dowd, D. J. \& Gill, A. M. (1986) Seed dispersal syndromes of Australian Acacia. Seed dispersal (ed. by D. Murray), pp. 87-121. Academic Press, New York.

Orians, G.H. \& Milewski, A.V. (2007) Ecology of Australia: the effects of nutrient-poor soils and intense fires. Biological Reviews, 82, 393-423.

Pedley, L. (1978). A revision of Acacia Mill. in Queensland. Austrobaileya, 1, 75-234.

Pedley, L. (1986). Derivation and dispersal of Acacia (Leguminosae), with particular reference to Australia, and the recognition of Senegalia and Racosperma. Botanical Journal of the Linnean Society, 92, 219-254.

Poynton, R.J. (2009) Tree planting in Southern Africa. Volume 3: other genera. Department of Agriculture, Forestry and Fisheries, Pretoria. 
Procheş, Ş., Richardson, D. M., Wilson, J. R. U. \& Rejmánek, M. (2011). Native and naturalised range size in Pinus: relative importance of biogeography, introduction effort and species traits. Global Ecology and Biogeography (in press) doi is 10.1111/j.1466-8238.2011.00703.x.

Pyšek, P. \& Richardson, D.M. (2007). Traits associated with invasiveness in alien plants: Where do we stand? Biological Invasions (ed. by W. Nentwig), pp. 97-125. Ecological Studies 193.

Springer, Berlin.

Pyšek, P. \& Richardson, D.M. (2010) Invasive species, environmental change and management, and ecosystem health. Annual Review of Environment and Resources, 35, 25-55.

Pyšek, P., Richardson, D.M., Rejmánek, M., Webster, G.L., Williamson, M. \& Kirschner, J. (2004) Alien plants in checklists and floras: towards better communication between taxonomists and ecologists. Taxon, 53, 131-143.

R Development Core Team (2010) R: a language and environment for statistical computing. $R$ Foundation for Statistical Computing, Vienna, Austria. Available at: http://www.R-project.org. Ratnayake, K. \& Joyce, D. (1978) Native Australian acacias: unrealised ornamental potential. Chronica Horticulturae, 50, 19-22.

Rejmánek, M. \& Richardson, D.M. (2011). Eucalypts. Encyclopedia of biological invasions (ed. by D. Simberloff and M. Rejmánek), pp. 203-209. University of California Press, Berkeley. Ricciardi A (2007) Are modern biological invasions an unprecedented form of global change? Conservation Biology, 21, 329-336.

Richardson, D.M. (1998) Forestry trees as invasive aliens. Conservation Biology, 12, 18-26.

Richardson, D.M. (2006) Pinus: a model group for unlocking the secrets of alien plant invasions? Preslia, 78, 375-388.

Richardson, D.M. (ed.) (2011a). Fifty years of invasion ecology. The legacy of Charles Elton. WileyBlackwell, Oxford.

Richardson, D.M. (2011b). Invasion science: The roads travelled and the roads ahead. Fifty years of invasion ecology. The legacy of Charles Elton (ed. by D.M. Richardson), pp, 397-407. WileyBlackwell, Oxford.

Richardson, D.M., Allsopp, N., D'Antonio, C.M., Milton, S.J. \& Rejmánek, M. (2000a) Plant invasions: The role of mutualisms. Biological Reviews, 75, 65-93.

Richardson, D.M., Binggeli, P. \& Schroth, G. (2004) Invasive agroforestry trees: problems and solutions. Agroforestry and Biodiversity Conservation in Tropical Landscapes (ed. by G. Schroth, G.A.B. de Fonseca, C.A. Harvey, C. Gascon, H. Vasconcelos and A.-M. N. Izac), pp. 371-396. Island Press, Washington, D.C.

Richardson, D.M., Pyšek, P., Simberloff, D., Rejmánek, M. \& Mader, A.D. (2008) Biological invasions - the widening debate: A response to Charles Warren. Progress in Human Geography, 32, 295-298. 
Richardson, D.M., Rouget, M. \& Rejmánek, M. (2004) Using natural experiments in the study of alien tree invasions: Opportunities and limitations. Experimental approaches to conservation biology (ed. by M.S. Gordon and S.M. Bartol), pp. 180-201. University of California Press, Berkeley.

Richardson, D.M., Rundel, P.W., Jackson, S.T., Teskey, R.O., Aronson, J., Bytnerowicz, A., Wingfield, M.J. \& Procheș, S. (2007) Human impacts in pine forests: past, present and future. Annual Reviews of Ecology, Evolution, and Systematics, 38, 275-297.

Richardson, D.M. \& Thuiller, W. (2007). Home away from home - objective mapping of high-risk source areas for plant introductions. Diversity and Distributions, 13, 299-323.

Richardson, D.M., van Wilgen, B.W. \& Nunez, M. (2008) Alien conifer invasions in South America - short fuse burning? Biological Invasions, 10, 573-577.

Richardson, D.M. \& Whittaker, R.J. (2010) Conservation biogeography - foundations, concepts and challenges. Diversity and Distributions, 16, 313-320.

Robinson, J. \& Harris, S.A. (2000) A plastid DNA phylogeny of the genus Acacia Miller (Acacieae, Leguminosae). Botanical Journal of the Linnean Society 132: 195-222.

Rodriguez-Echeverria, S. (2010) Rhizobial hitchhikers from Down Under: invasional meltdown in a plant-bacteria mutualism? Journal of Biogeography, 37, 1611-1622.

Rodríguez-Echeverría, S., Le Roux, J.J., Crisóstomo, J.A. \& Ndlovu, J. (2011) Jack-of-all-trades and master of many? How does associated rhizobial diversity influence the colonization success of Australian acacias? Diversity and Distributions, 17 (in press). DOI: 10.1111/j.14724642.2011.00787.x.

Roura-Pascual, N., Krug, R.M., Richardson, D.M. \& Hui, C. (2010) Spatially-explicit sensitivity analysis for conservation management: exploring the influence of decisions in invasive alien plant management. Diversity and Distributions, 16, 426-438.

Simberloff, D. Nuñez, M., Ledgard, N.J., Pauchard, A., Richardson, D.M, Sarasola, M., van Wilgen, B.W., Zalba, S.M., Zenni, R.D., Bustamante, R., Peña, E. \& Ziller, S.R. (2010) Spread and impact of introduced conifers in South America: Lessons from other southern hemisphere regions. Austral Ecology, 35, 489-504.

Thompson, G.D., Robertson, M.P., Webber, B.L., Richardson, D.M., Le Roux, J.J. \& Wilson, J.R.U. (2011) Predicting the sub-specific identity of invasive species using distribution models: Acacia saligna as an example. Diversity and Distributions, 17 (in press).

Tucker, K.C. \& Richardson, D.M. (1995) An expert system for screening potentially invasive alien plants in South Africa fynbos. Journal of Environmental Management, 44, 309-338.

Van Wilgen, B.W., Dyer, C., Hoffmann, J.H., Ivey, P., Le Maitre, D.C., Richardson, D.M., Rouget, M., Wannenburgh, A. \& Wilson, J.R.U. (2011) A strategic approach to the integrated management of 
Australian acacias in South Africa. Diversity and Distributions, 17 (in press). DOI:

10.1111/j.1472-4642.2011.00785.x

Vassal, J. (1972) Apport des recherches ontogeniques et seminologiques a l'etude morphologique, taxonomique et phylogenique du genre Acacia. Bulletin de la societe d'histoire naturelle de Toulouse 108, 105-247.

Veldtman, R., Lado, T.F., Botes, A., Proches, S., Timm, A.E., Geertsema, H. \& Chown, S.L. (2011). Creating novel food webs on introduced Australian acacias: indirect effects of galling biological control agents. Diversity and Distributions, 17 (in press). DOI: 10.1111/j.1472-

4642.2011.00781.x.

Warren, C.R. (2007) Perspectives on the 'alien' versus 'native' species debate: a critique of concepts, language and practice. Progress in Human Geography, 31, 427-46.

Warren, C.R. (2008) Alien concepts: a response to Richardson et al. Progress in Human Geography, 32, 299-300.

Webber, B.L., Yates, C.J., Le Maitre, D.C., Scott, J.K., Kriticos, D.J., Ota, N., McNeill, A., Le Roux, J.J. \& Midgley, G.F. (2011) Modelling horses for novel climate courses: insights from projecting potential distributions of native and alien Australian acacias with correlative and mechanistic models. Diversity and Distributions, 17 (in press). DOI: 10.1111/j.1472-4642.2011.00811.x Willdenow, C.L. (1806) Caroli a Linne Species Plantarium. Ed. 4, vol.4. Berlin.

Wilson, J.R.U., Dormontt, E.E., Prentis, P.J., Lowe, A.J. \& Richardson, D.M. (2009) Something in the way you move: dispersal pathways affect invasion success. Trends in Ecology \& Evolution, 24, 136-144.

Wilson, J. R. U., Gairifo, C., Gibson, M. R., Arianoutsou, M., Bakar, B.B., Baret, S., Celesti-Grapow, L., DiTomaso, J.M., Dufour-Dror, J.-M., Kueffer, C., Kull, C.A., Hoffmann, J.H., Impson, F.A.C., Loope, L.L., Marchante, E., Marchante, H., Moore, J.L., Murphy, D.J., Tassin, J., Witt, A., Zenni, R.D. \& Richardson, D.M. (2011) Risk assessment, eradication, and biological control: global efforts to limit Australian acacia invasions. Diversity and Distributions, 17 (in press). DOI: 10.1111/j.14724642.2011.00815.x

Wingfield, M.J. Roux, J. \& Wingfield, B.D. (2011) Insect pests and pathogens of Australian acacias grown as non-natives - an experiment in biogeography with far reaching consequences.

Diversity and Distributions, 17 (in press). DOI: 10.1111/j.1472-4642.2011.00786.x 


\section{LIST OF TABLES, APPENDICES AND FIGURES}

Table 1 Lists of Australian Acacia species relevant to different points on the introductionnaturalisation-invasion continuum. Each list is related to the different stages in the unified framework for biological invasions using the A-E scheme proposed by Blackburn et al., 2011 (see Fig. 4 for a definition of the categories). Lists from South Africa were included in additional to the global lists as an example of regional application of lists. For further details and the actual data see Supplementary Files 1.

Table 2 All Australian Acacia species and the furthest point along the introductionnaturalisation-invasion continuum that they are recorded as having reached (see Table 1, Fig. 4, Supplementary File 2).

Appendix 1. Acacia then and now - a brief history of the taxonomy of the group.

Appendix 2. Methods used to map potential distributions of Australian acacias outside Australia

\section{FIGURE CAPTIONS}

Figure 1 Species richness of Australian Acacia species across Australia (shading indicates number of taxa in half-degree cells). The inset shows the main categories of Australian agroclimatic classes (Hutchinson et al., 2005). Major categories indicated on the map are: B (cold); D (cool wet); E (warm, seasonally wet/dry; E1 is classic "Mediterranean" climate, E2 is "Mediterranean"-type climate, but with drier cooler winters and less growth potential than in E1); F (warm, wet); G (warm to hot, very dry); H (hot, dry); I (hot, seasonally wet/dry); and J (hot, wet).

Figure 2 The number of invasive Australian Acacia species known in each of 15 regions of the world (Richardson \& Rejmanek, 2011) and a map of areas climatically suitable for Australian acacias. Shading indicates number of species that could potentially grow in different areas. Results are based on a bioclimatic analysis using a simple envelope approach using all taxa of Australian acacias from Australia's Virtual Herbarium (2010) with 6 or more records (838 species were used to produce the map). Methods used in generating the map are described in Appendix 2. 
Figure 3 Examples of landscapes in different parts of the world dominated by Australian acacias. A) Plantation of Acacia crassicarpa in Riau Province, Sumatra (photo: S.J. Midgley); b: Derelict A. mangium plantation (foreground) with undisturbed tropical dipterocarp forest in the background in Sampadi, Lundu district, Sarawak, Malaysia (photo: B. Bakar); c: A. mangium plantation in Sumatra, Indonesia (photo: M.J. Wingfield); d: Self-sown A. salicina growing the Negev desert, Israel (photo: J.-M. Dufour-Dror); e: A natural hybrid of A. auriculiformis and $A$. mangium growing on previously bare and overgrazed land between Vinh and Hanoi, Vietnam (photo: S.J. Midgley); f: Commercial A. mearnsii plantation in KwaZulu-Natal, South Africa (photo: G. Chigeza); g: Invasive A. dealbata near Coimbra, Portugal (photo: D.M. Richardson); h: Invasive A. dealbata near Concepcion, Chile (individual with pods in right foreground) (photo: D.M. Richardson); i: Mixed stand of invasive trees in the Western Cape, South Africa, with $A$. pycnantha in the foreground (photo: D.M. Richardson); j: A. cyclops invading fynbos vegetation, Western Cape, South Africa (photo: D.M. Richardson); k: A. mearnsii invading riparian vegetation, Western Cape, South Africa (photo: D.M. Richardson); l: A. saligna invading near Skarinou, Cyprus (photo: C. Christodoulou).

Figure 4 Key issues emerging from Australian acacia introductions as a natural experiment based on the papers in this special issue. These papers are mapped onto relevant points of the proposed unified framework for biological invasions (adapted from Blackburn et al., 2011). The numbers in square brackets refer to the papers in the species issue (see below). A) The number of species in each introduction category (i.e. the state) based on Tables 1 and 2. The full data are in Appendix S1 (see below for the definitions of the categories); B) The biotic and abiotic barriers to invasion; C) How humans have facilitated the process of Australia acacia movements and invasions; D) Management actions.

Category definitions: A1: No individuals transported beyond limit of native range; A2: Historically transported but no longer found outside Australia; B1: Individuals transported beyond native range and kept in captivity or quarantine; B2: Individuals transported beyond limits of native range, and in cultivation; B3: Individuals transported beyond limits of native range, and directly released into novel environment; C0: Individuals released into the wild in location where introduced, but incapable of surviving for a significant period; C1: Individuals surviving in the wild, no reproduction; C2: Individuals surviving and reproducing in the wild, but no populations self-sustaining; D1: self-sustaining population in wild individuals dispersing a significant distance and surviving; D2: as D1, but individuals also reproducing a significant distance from the parent plant; E: invasive across several habitats. 
References: [1] This paper; [2] Richardson \& Rejmánek (2011); [3] Carruthers et al. (2011); [4] Kull et al.(2011); [5] Griffin et al.(2011); [6] Miller et al.(2011); [7] Le Roux et al.(2011); [8] Hui et al.(2011); [9] Gallagher et al.(2011); [10] Morris et al.(2011); [11] Gibson et al.(2011); [12] Castro-Díez et al.(2011); [13] Rodriguez-Echeverria et al.(2011); [14] Veldtman et al.(2011); [15] Wingfield et al.(2011); [16] Webber et al.(2011); [17] Thompson et al.(2011); [18] Le Maitre et al.(2011); [19] Wilson et al.(2011); [20] Moore et al.(2011); [21] van Wilgen et al.(2011).

Figure 5 Cluster analysis with Ward linkage rule of the 1012 Australian Acacia species according to their occurrence (using records from Australia's Virtual Herbarium) in 18 Australian agro-climatic classes (Hutchinson et al., 2005; see Figure 1). Different subsets of species are colour-coded: (i) those not known to have been introduced outside Australia (yellow); (ii) those introduced but not known to have naturalised (green); (iii) those known to have naturalised (blue); and (iv) 23 invasive species (Richardson \& Rejmánek, 2011)(red). The three maps show the combined distributions of three groups of invasive species.

\section{SUPPORTING INFORMATION}

Additional Supporting Information may be found in the online version of this article:

Supplementary File Appendix S1. A database of different lists of Australian Acacia species used to identify the introduction status of each species (as per Figure 4; with some of the sources summarised in Table 1). 
Table 1

\begin{tabular}{|c|c|c|c|c|c|}
\hline & List & Usage & Numbers & Description & References \\
\hline & $\begin{array}{l}\text { All Acacia } \\
\text { species in } \\
\text { subgenus } \\
\text { Phyllodineae } \\
\text { that have } \\
\text { Australia as } \\
\text { part of their } \\
\text { native range }\end{array}$ & $\begin{array}{l}\text { Total } \\
\text { number of } \\
\text { species (also } \\
\text { used as a } \\
\text { reference list } \\
\text { of names) }\end{array}$ & $\begin{array}{l}1012 \text { (A-E) } \\
\text { [note there } \\
\text { are a total of } \\
1022 \text { Acacia } \\
\text { species in } \\
\text { subgenus } \\
\text { Phyllodineae] }\end{array}$ & $\begin{array}{l}\text { The list of valid species as defined in the special issue. Hybrids and crosses are not included, and infra-specific } \\
\text { information is ignored. There are several groups, in particular the Acacia aneura complex, where new species are } \\
\text { currently being described and it is estimated that there are up to } 100 \text { undescribed species (Maslin et al., 2003). } \\
\text { However, given the extensive taxonomic work done on this group in Australia, it is likely this list represents } 90 \% \text { of } \\
\text { species. Most of these species are native exclusively to Australia, only } 17-20 \text { species have a native range extending } \\
\text { outside Australia and only } 10 \text { are exclusively non-Australian. There are also two species of Acacia subgenus } \\
\text { Aculeiferum and seven species of Acacia subgenus Acacia native to Australia. }\end{array}$ & $\begin{array}{l}\text { Australia's Virtual } \\
\text { Herbarium } \\
\text { (accessed 29 June } \\
\text { 2010); } \\
\text { World Wide Wattle, } \\
\text { (accessed Dec } \\
\text { 2010); B. Maslin } \\
\text { (pers. comm., 2010, } \\
\text { 2011); } \\
\end{array}$ \\
\hline \multirow{7}{*}{$\begin{array}{l}\frac{\pi}{0} \\
\frac{0}{0} \\
\end{array}$} & $\begin{array}{l}\text { All records of } \\
\text { introduction }\end{array}$ & $\begin{array}{l}\text { Number of } \\
\text { introduced } \\
\text { species }\end{array}$ & $386(\mathrm{~A} 2-\mathrm{E})$ & $\begin{array}{l}\text { The number of Australian acacias that have been introduced to countries outside Australia, a combination of all the } \\
\text { lists below. While there are many clear examples of human-mediated dispersal of acacias within Australia these are } \\
\text { not included as intra-Australia dispersal cannot always be definitively ascribed to human activities. }\end{array}$ & This paper. \\
\hline & $\begin{array}{l}\text { All records of } \\
\text { naturalisation }\end{array}$ & $\begin{array}{l}\text { Number of } \\
\text { naturalised } \\
\text { species }\end{array}$ & $71(\mathrm{C} 2-\mathrm{E})$ & $\begin{array}{l}\text { The number of Australian acacias that have naturalised in countries other than Australia according to Global } \\
\text { Compendium of Weeds (GCW). This list includes one species, A. holosericea, that has been recorded as invasive but } \\
\text { was not included in the GCW at the time the database was accessed. }\end{array}$ & This paper. \\
\hline & $\begin{array}{l}\text { Confirmed } \\
\text { records of } \\
\text { invasion }\end{array}$ & $\begin{array}{l}\text { Number of } \\
\text { invasive } \\
\text { species }\end{array}$ & $23(\mathrm{E})$ & $\begin{array}{l}\text { Data on Australian acacias from a global review of invasive alien trees and shrubs. The list only includes species for } \\
\text { which there is clear evidence of invasion (sensu Pyšek et al.,2004). }\end{array}$ & $\begin{array}{l}\text { Richardson \& } \\
\text { Rejmánek (2011) }\end{array}$ \\
\hline & $\begin{array}{l}\text { Australian Tree } \\
\text { Seed Centre } \\
\text { (ATSC) }\end{array}$ & $\begin{array}{l}\text { Number of } \\
\text { introduced } \\
\text { species }\end{array}$ & 299 (A2-E) & $\begin{array}{l}\text { Export records of seed-lots sent from Australian Tree Seed Centre (CSIRO, Australia) to other countries around the } \\
\text { world, 1980-2010. Data on the number of regions to which seed-lots were sent, and the number of seed-lots are } \\
\text { also available (total of } 49052 \text { seed lots). }\end{array}$ & Griffin et al.(2011) \\
\hline & $\begin{array}{l}18^{\text {th }} \text { and } 19^{\text {th }} \\
\text { century } \\
\text { introductions }\end{array}$ & $\begin{array}{l}\text { Number of } \\
\text { introduced } \\
\text { species }\end{array}$ & $98(\mathrm{~A} 2-\mathrm{E})$ & $\begin{array}{l}\text { List of species introduced and cultivated in Europe. This represents among one of the first waves of botanical } \\
\text { samples sent from Australia. Many of the species were likely sent on from their original location. Around } 178 \\
\text { introductions which can be tied to current names, but a further } 40 \text { or so are only known by their horticultural } \\
\text { names. }\end{array}$ & Cavanagh (2006) \\
\hline & $\begin{array}{l}\text { Herbarium } \\
\text { records (GBIF) }\end{array}$ & $\begin{array}{l}\text { Number of } \\
\text { introduced } \\
\text { species }\end{array}$ & $\begin{array}{l}\text { 143-151(A2- } \\
\text { E) }\end{array}$ & $\begin{array}{l}\text { This list, based on } 5580 \text { herbarium records, is of samples collected outside Australia. The list is taken as evidence } \\
\text { that mature plants were grown outside Australia at some point in time. As } 8 \text { species recorded have native ranges } \\
\text { extending outside Australia, there is some uncertainty about whether the herbarium records collected for these } \\
\text { plants were following an introduction. Around } 5 \% \text { of all herbarium records downloaded were not used as they } \\
\text { could not be given a valid name, or rejected as an obvious error, or removed because of no location data. }\end{array}$ & $\begin{array}{l}\text { Global Biodiversity } \\
\text { Information Facility } \\
\text { (accessed } 20 \text { July } \\
2010 \text { ) }\end{array}$ \\
\hline & $\begin{array}{l}\text { Global } \\
\text { Compendium of } \\
\text { Weeds (GCW) }\end{array}$ & $\begin{array}{l}\text { Number of } \\
\text { naturalised } \\
\text { and number } \\
\text { of invasive } \\
\text { species }\end{array}$ & $\begin{array}{l}70(\mathrm{C} 3-\mathrm{E}) \\
16(\mathrm{E})\end{array}$ & $\begin{array}{l}\text { Based on records returned from a search of the term "Acacia" in the GCW. After sorting for valid Australian acacias } \\
\text { and excluding } 7 \text { species that are only recorded as naturalised in Australia and that have not been recorded as } \\
\text { introduced in either ATSC or GBIF, this gave } 924 \text { records that state a species is a "weed" or a similar synonym. We } \\
\text { have assumed that the presence on this list is evidence of naturalisation (i.e. escape from cultivation and self- } \\
\text { sustaining population), and that if a record states it as "invasive" then it is. }\end{array}$ & $\begin{array}{l}\text { Randall (2002) and } \\
\text { May } 2010 \text { update of } \\
\text { Global Compendium } \\
\text { of Weeds supplied } \\
\text { by R.P. Randall. } \\
\end{array}$ \\
\hline \multirow{2}{*}{ 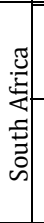 } & $\begin{array}{l}\text { South African } \\
\text { Herbarium } \\
\text { records }\end{array}$ & $\begin{array}{l}\text { Number of } \\
\text { introduced } \\
\text { species }\end{array}$ & 69 (A2-E) & 747 herbarium records of plants as part of the cultivated plant collection. Lists edited as for global list. & $\begin{array}{l}\text { H. Glen (pers. } \\
\text { comm. 2009) }\end{array}$ \\
\hline & $\begin{array}{l}\text { Experimental } \\
\text { forestry } \\
\text { introductions }\end{array}$ & $\begin{array}{l}\text { Success of } \\
\text { introduction }\end{array}$ & $\begin{array}{l}3(\mathrm{~B} 2) \\
11(\mathrm{~B} 2-\mathrm{E}) \\
5(\mathrm{C} 3-\mathrm{D} 2) \\
12(\mathrm{E})\end{array}$ & $\begin{array}{l}\text { Records of historical forestry trials for southern Africa. Many of these species may no longer be present (and so } \\
\text { A2). Provides an indication of species, location, and result of introduction, but it is known to not be a complete list, } \\
\text { e.g. it does not include A. implexa, and some errors have been identified, e.g. A. paradoxa is much more widespread } \\
\text { than recorded (Zenni et al.,2009). }\end{array}$ & Poynton (2009) \\
\hline
\end{tabular}




\begin{tabular}{|c|c|c|c|c|}
\hline List & Usage & Numbers & Description & References \\
\hline $\begin{array}{l}\text { Southern } \\
\text { African Plant } \\
\text { Invaders Atlas } \\
\text { (SAPIA) }\end{array}$ & $\begin{array}{l}\text { Number of } \\
\text { naturalised } \\
\text { or invasive } \\
\text { species }\end{array}$ & $\begin{array}{l}1(\mathrm{C} 3 \\
\text { presumed A2) } \\
2(\mathrm{C} 3) \\
2(\mathrm{D} 1) \\
14(\mathrm{E})\end{array}$ & $\begin{array}{l}\text { Record of the species outside of cultivation with the following updates: } A \text {. cultriformis has not been confirmed and is } \\
\text { not included here; A. fimbriata is recorded as naturalised and a herbarium sample was taken several decades ago, } \\
\text { but no plants are now present at the site (so presumed A2); A few plants of A. retinoides and A. ulicifolia are } \\
\text { persisting and recruiting at Tokai Arboretum (C3), A. viscidula and A. adunca have naturalised and shown some } \\
\text { propensity for local spread (D1), all other species show significant spread and recruitment beyond the point of } \\
\text { introduction (E). }\end{array}$ & $\begin{array}{l}\text { Southern African } \\
\text { Plant Invaders Atlas } \\
\text { (accessed March } \\
\text { 2009) also J. Wilson } \\
\text { pers. obs. } 2011\end{array}$ \\
\hline
\end{tabular}


Table 2

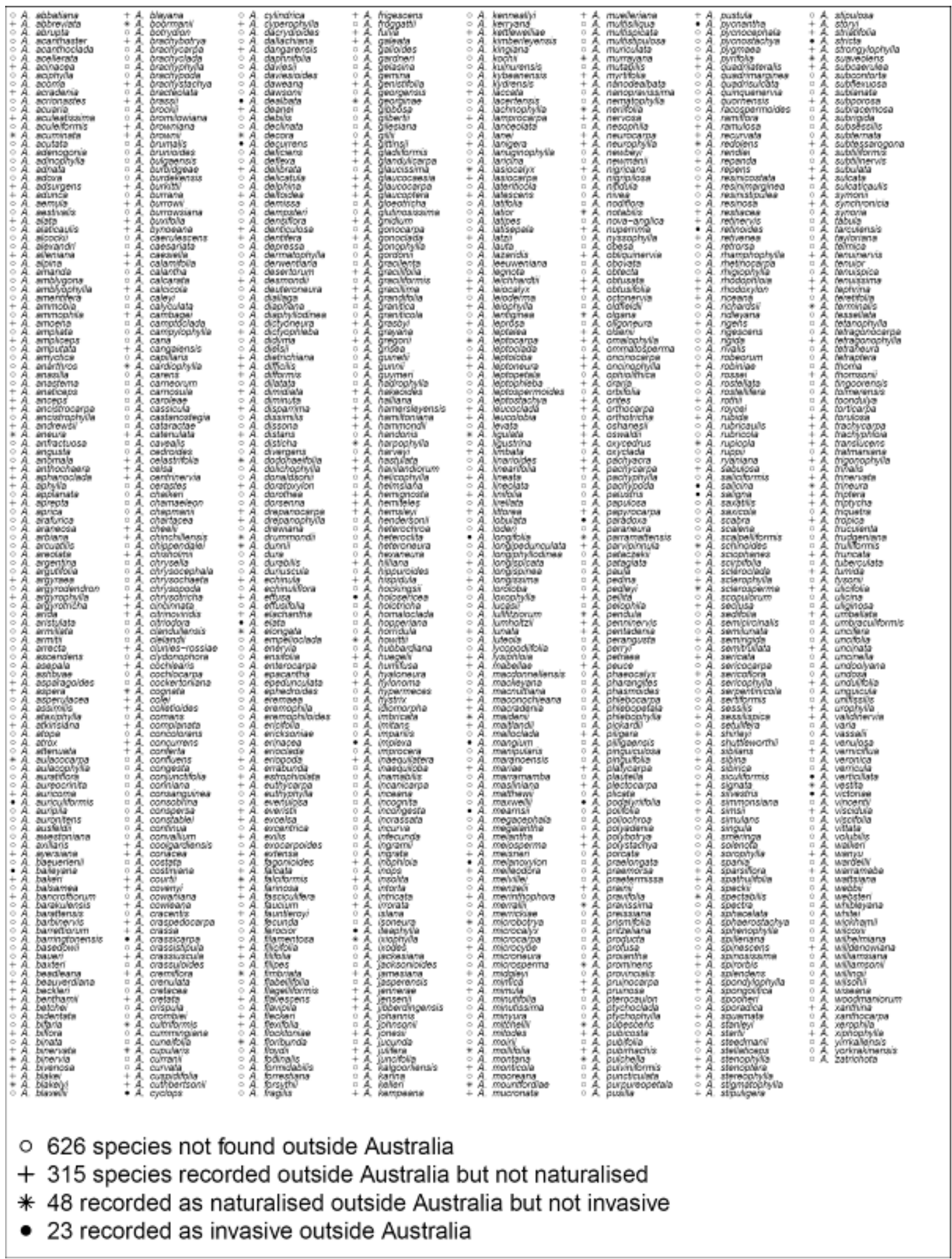


Appendix 1. Acacia then and now - a brief history of the taxonomy of the group.

The genus Acacia was originally described by P. Miller in 1754 from an African species (Acacia senegal) and early definitions included many species of Mimosoideae legumes that are no longer part of Acacia sensu lato (Miller, 1754; Willdenow, 1806; Candolle, 1825). In a series of works in the mid-19th century, Bentham (1875) circumscribed Mimosoideae tribes and within it Acacia, diagnosed by having infinite free stamens, into the broad forms we know today. However, based on current knowledge of the group, there are no defining morphological characters that differentiate Acacia sensu lato from other genera of the Tribes Mimoseae and Ingeae (Maslin et al., 2003). Pedley (1986), generally following Vassal's (1972) subgeneric classification, proposed that the genus be dived into three genera: Acacia, Senegalia and Racosperma. This work initiated investigations into Acacia to determine whether indeed Acacia sensu lato was polyphyletic and what characters differentiated the putative segregate genera. A detailed overview of the generic history of Acacia is provided by Maslin et al.(2003).

The first molecular studies focused on either the African or American species but did not sample broadly enough to determine broader relationships (Clarke et al., 2000; Robinson \& Harris, 2000). The first broad-scale studies using DNA sequences (Miller \& Bayer, 2000, 2001) determined that the genus was polyphyletic, containing three distinct lineages broadly conforming to the Vassal (1972) and Pedley (1986) taxonomy. This was confirmed by larger studies of the Mimosoideae (Luckow et al,. 2003) and Ingeae (Brown et al., 2008). A review of the molecular systematics of Acacia sensu lato is provided by Miller et al.(2011). This work showed that Acacia subgenus Acacia is embedded within Tribe Mimoseae and that the mainly Australian acacias of Acacia subgenus Phyllodineae are more closely related to a paraphyletic tribe Ingeae than to other species in Acacia sensu lato. Amid controversy (McNeil \& Turland, 2010; Moore et al., 2010), the type of the genus was changed from the African A. nilotica to the Australian species A. penninervis at the International Botanical Congress in 2005.

Acacia s.l. in the broad sense has three main centres of diversity. Both the Americas and Africa are home to both Acacia subgenus Acacia (Vachellia) and Acacia subgenus Aculeiferum (Senegalia) while the large radiation of Acacia subgenus Phyllodineae is mainly found in Australia. Indeed $\sim 99 \%$ of Australian Acacia species belong to Acacia subgenus Phyllodineae (Table 1), and similarly 99\% of Acacia subgenus Phyllodineae are native to Australia. While Acacia sensu lato can be found in many environments it comprises a major component of arid and semi-arid zones in Australia, African and the Americas. With one exception, all Acacia species not assigned to Acacia subgenus Phyllodineae have bipinnate leaves. These species, including over $95 \%$ of the Australian species, have modified leaves called phyllodes. Other characters that are common but not found in all Australian Acacia species include extraporate 
pollen with a reticulate exine, inflorescences that are either simple or racemose with flowers arranged in globular heads or cylindrical spikes. Most often the inflorescences are golden yellow or creamish white.

Pedley (1978) developed a sectional classification of Acacia subgenus Phyllodineae that included seven groups based mainly on leaf and inflorescence characters. While the sections have not been considered natural groupings they provided a convenient method of describing the vast diversity of the group. Two small groups contained only bipinnate species: Pulchellae from SW Western Australia and the Botrycephalae for SE Australia. Two other small nonphyllodinous groups, sections Lycopodiifoliae and Alatae are found in Western and northern Australia. There are two main types of phyllodes those that contain a single main nerve (section Phyllodineae) and those with multiple nerves (section Plurinerves which has globose inflorescences and section Juliflorae with spicate inflorescences). Together, these three sections comprise $\sim 90 \%$ of the species. Molecular systematic work is beginning to develop the basis for a phylogenetic based classification of the genus (Murphy et al., 2010; Miller et al., 2011). While few if any of these taxonomic sections are monophyletic in molecular analyses, the phylogenetic patterns will help unravel character evolution of important reproductive traits (Gibson $e t$ al.,2011) and traits that may allow their high level of invasiveness (Gallagher et al., 2011). The latest phylogenetic tree of Acacia identifies areas that require further taxonomic and genetic work based on poor resolution of relationships. The least resolved part of the tree contains the bipinnate and uninerved racemose species which are generally found in SE Australia (Figure 3 in Miller et al., 2011). This clade, which contains nine invasive species, is well supported but there is little resolution within it. Hybridization, lineage sorting, lack of taxonomic effort are probable reasons for this result and it will require detailed genetic and taxonomic research to resolve. 
Appendix 2. Methods used to map potential distributions of Australian acacias outside Australia

We used six interpolated bioclimatic variables (10 minute spatial resolution) obtained from WorldClim (www.worldclim.com; Hijmans et al., 2005) as predictor variables for developing simple climate envelope models for each species. These variables included: maximum temperature of warmest month, minimum temperature of coldest month, precipitation of wettest quarter, precipitation of driest quarter, precipitation of warmest quarter and precipitation of coldest quarter.

We obtained a dataset of occurrence records for 1020 Australian acacias from Australia's Virtual Herbarium. To reduce spatial sampling bias we retained only one occurrence record per 10 minute grid cell for each species. We then excluded all species for which there were fewer than five independent records, leaving a total of 838 species for which potential distribution models could be developed.

For each species we calculated the 1st and 99th percentile for values extracted from occurrence records for each predictor variable. These percentiles were used to identify the range of values that each species could tolerate for each predictor variable. We used this approach to minimize the effect of possible outliers that could have been present in the dataset due to misidentification errors. For each species, we reclassified each of the six predictor variable maps into a map consisting of presence (value $=1$ ) or absence (value $=0$ ), using the percentile values calculated for that species. We then multiplied these presence-absence maps to generate a final map indicating the potential distribution of that species. We added the potential distribution maps for all 838 species to generate a map of potential species richness. The analysis was conducted using R statistical software (v. 2.11, R Development Core Team, 2010). 
Figure 1

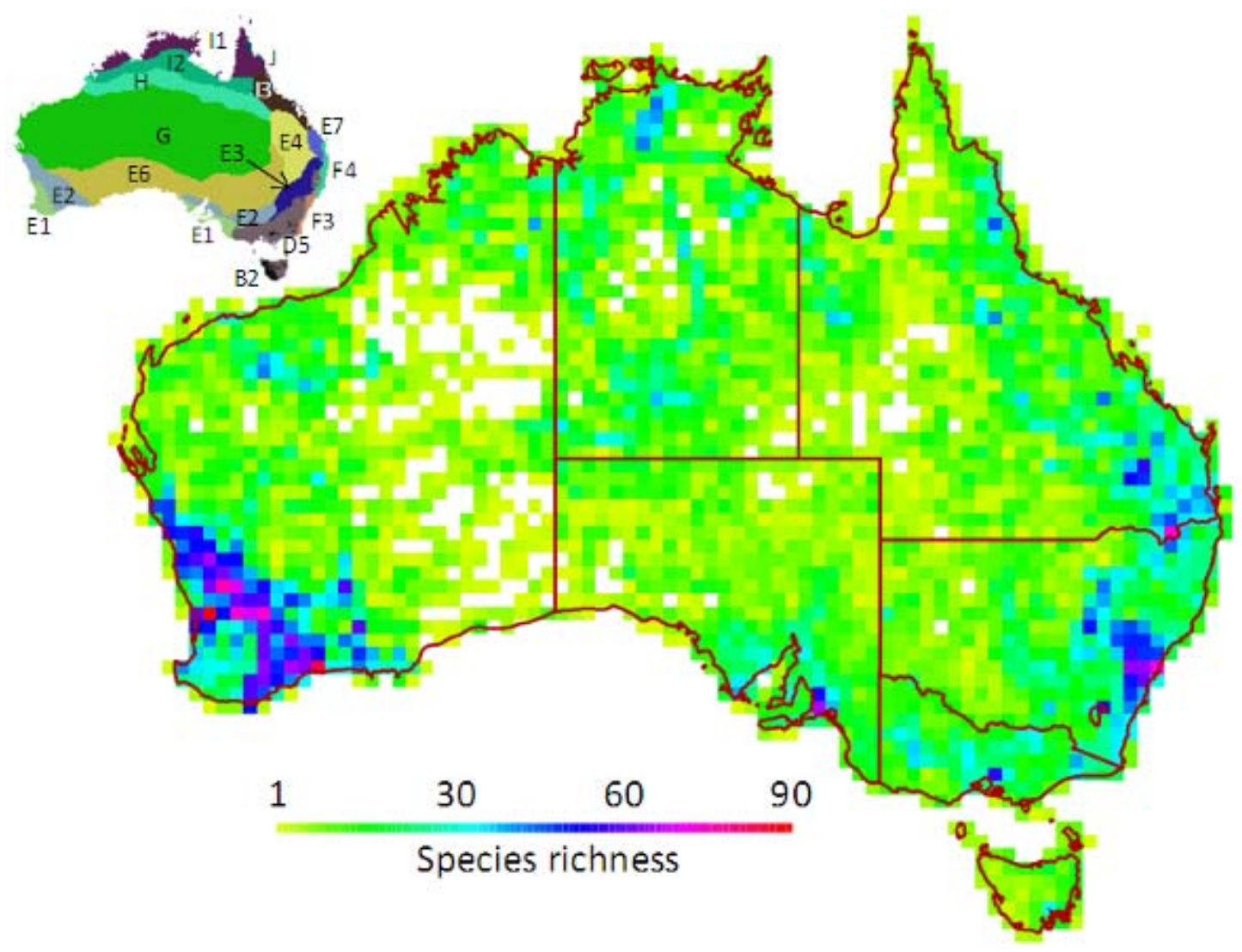


Figure 2

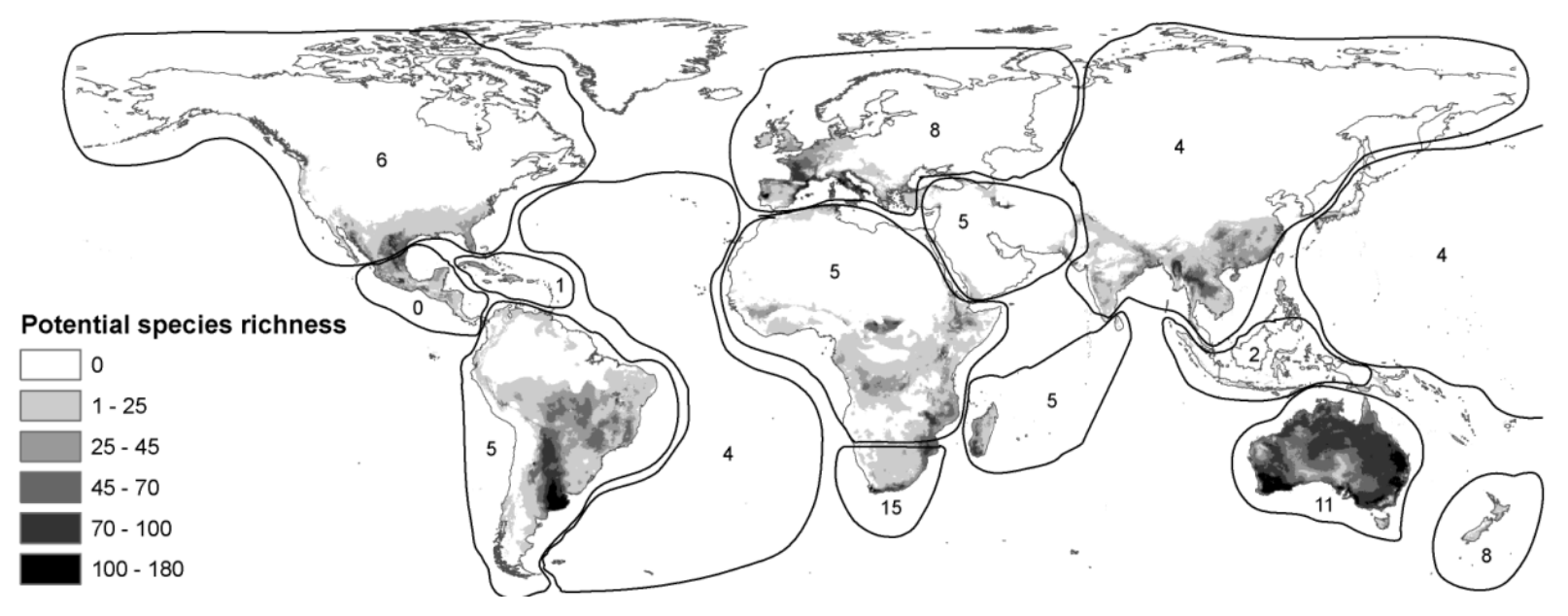


Figure 3

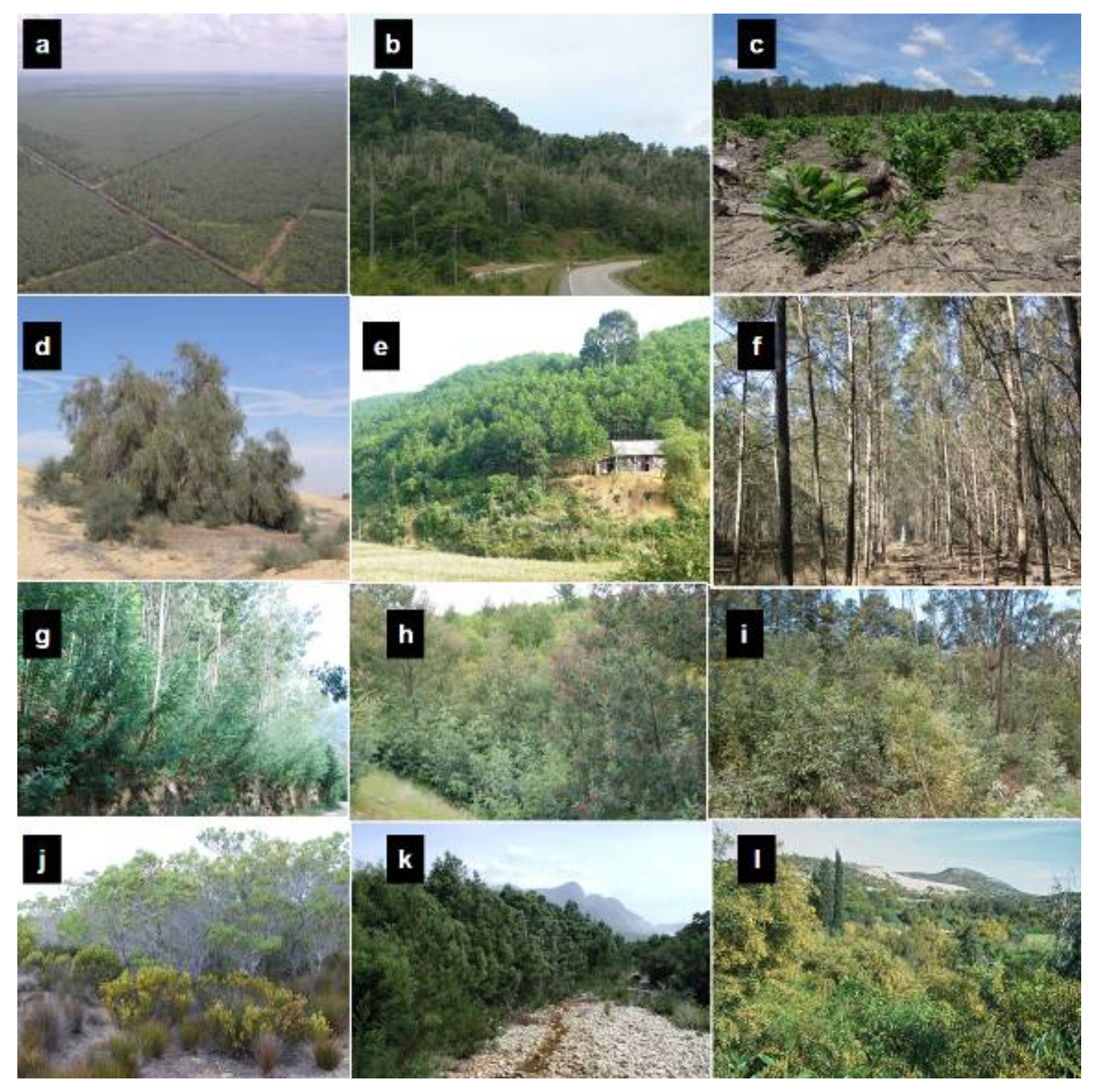




\section{Figure 4}

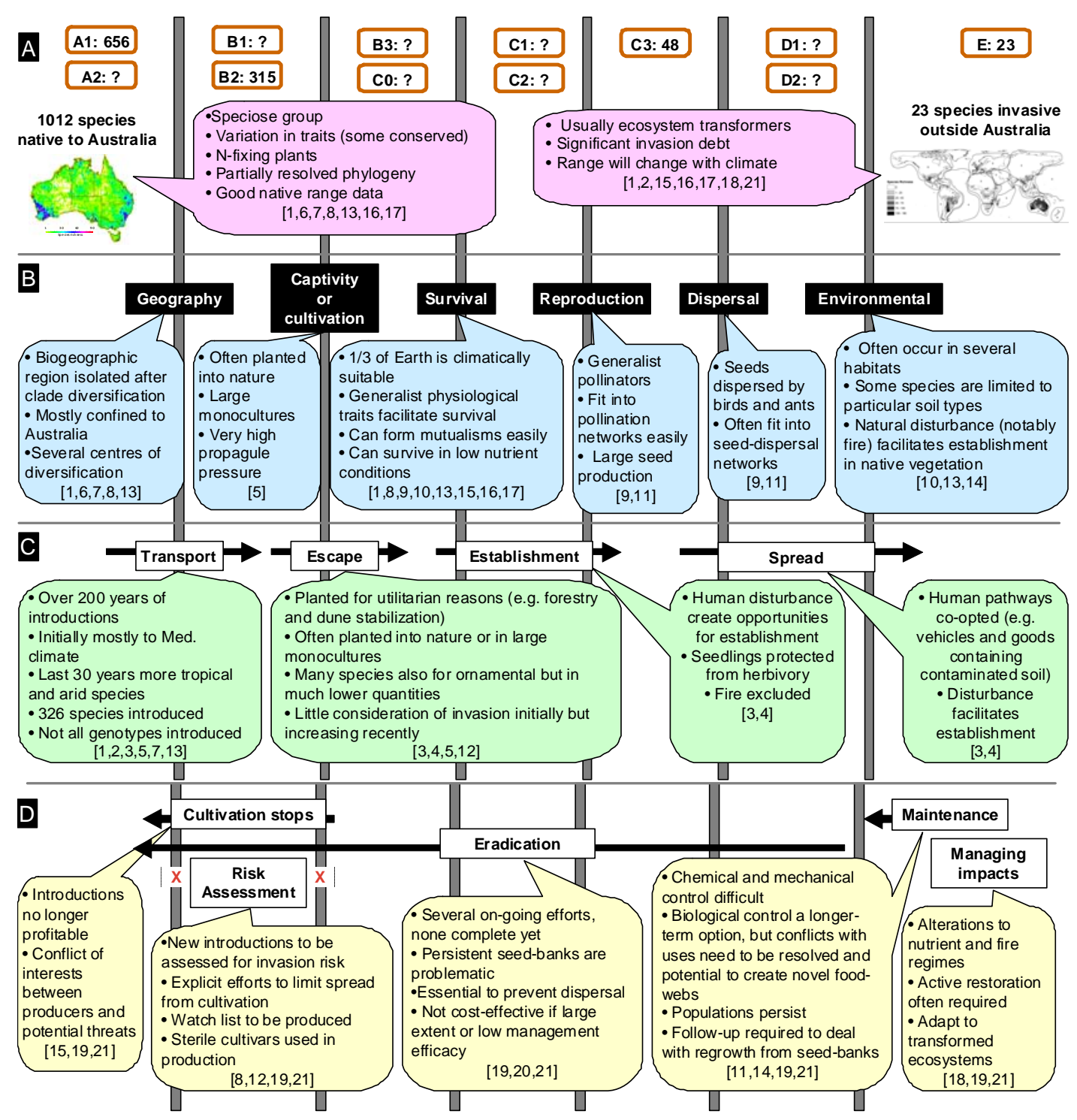




\section{Figure 5}

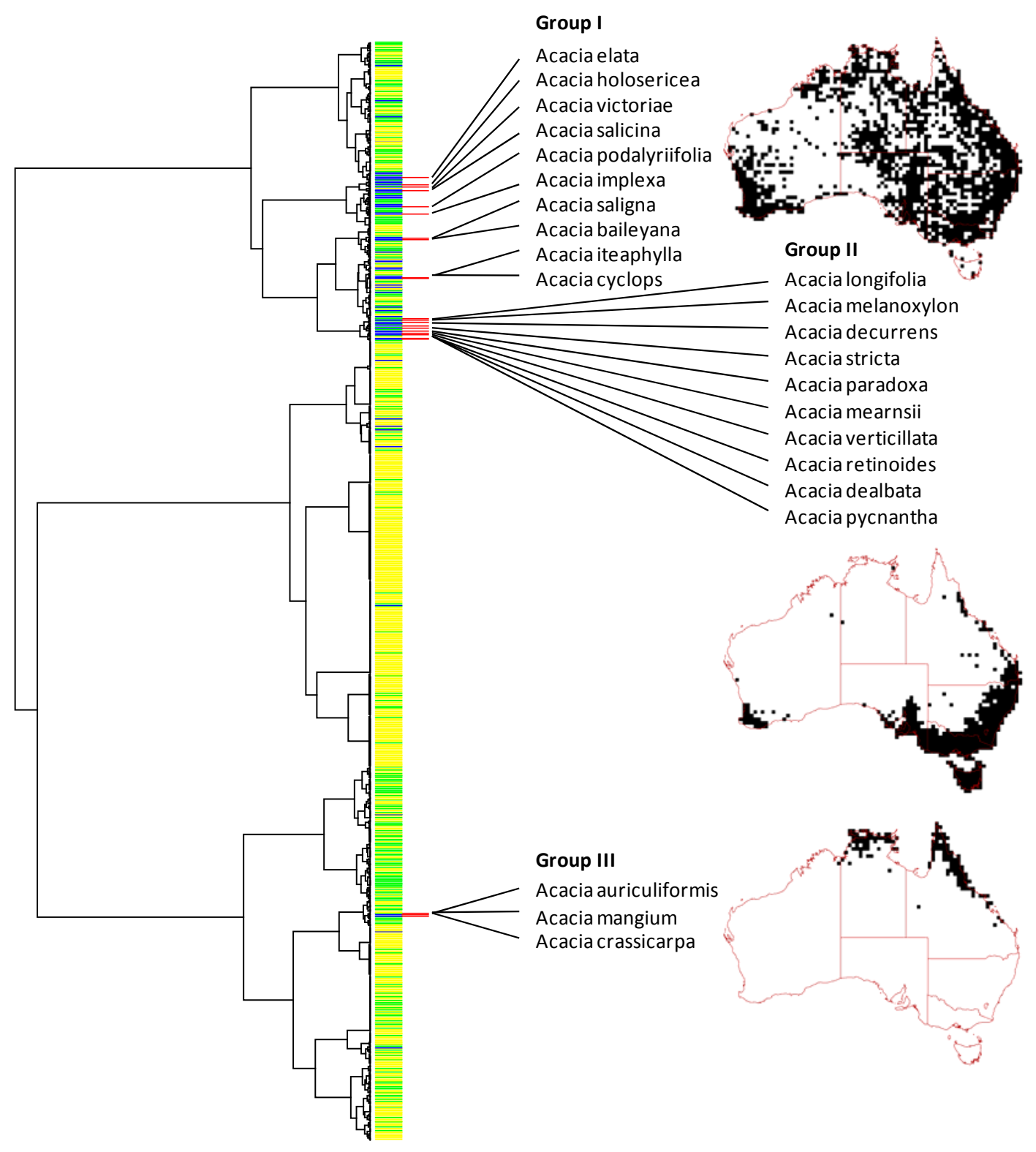


